\author{
PATRYCJA BRUDZIŃSKA \\ Uniwersytet Mikołaja Kopernika \\ $w$ Toruniu
}

\title{
ŚWIATOWE REPERKUSJE BADAŃ PISA. WOKÓŁ NOWEJ KONTROLI EDUKACJI
}

\begin{abstract}
Brudzińska Patrycja, Światowe reperkusje badań PISA. Wokót nowej kontroli edukacji [Global Repercussions of the PISA Research. Surrounding the New Education Control]. Studia Edukacyjne nr 51, 2018, Poznań 2018, pp. 227-236. Adam Mickiewicz University Press. ISSN 1233-6688. DOI: 10.14746/ se.2018.51.13
\end{abstract}

The paper presents the reactions of societies to the results of the Program for International Students Assessments (PISA) and some of the effects of this research. It presents education reforms and changes in education systems introduced as a consequence of confrontation of results achieved by fifteen-year-olds from different countries. The text describes examples of participants from Europe, America and Asia.

Key words: PISA research, global educational reform, educational competition, global educational systems

Od chwili publikacji pierwszych wyników badań Programme for International Students Assesments (PISA), prowadzonych przez Organizację Współpracy Gospodarczej i Rozwoju (OECD), dokonanych w 2000 roku (mimo upływu prawie dwóch dekad) nie cichnie dyskusja na temat uzyskiwanych przez badane kraje rezultatów. Ma ona swoje specyficzne tempo i co trzy lata (po każdorazowej publikacji wyników) skupia uwagę społeczeństw na efektywności systemu edukacyjnego, bo właśnie do przemyśleń nad efektywnością tychże systemów próbują namawiać twórcy artykułów (często nienaukowych) skierowanych do szerokiego grona odbiorców (polityków, nauczycieli, rodziców). Dyskusja ta ma również swoje swoiste natężenie, zależne od tego w jakim kraju uczestniczącym w badaniu jest toczona. W przededniu opublikowania kolejnych wyników badań - PISA 2018 i przed rozpoczęciem kolejnej dyskusji na ich temat pragnę przyjrzeć się kwestiom związanym nie tyle z osiągnięciami poszczególnych krajów, co z niektórymi efektami przeprowadzania tychże badań w krajach uczestniczących. 


\section{Reakcje społeczeństw na wyniki badań PISA}

Reakcje społeczeństw poszczególnych krajów po zapoznaniu się z rankingami przygotowywanymi przez OECD bywają skrajne. W tej części artykułu wskażę przykłady obrazujące to zjawisko zarówno wśród uczestników z Europy, jak i Azji czy Ameryki Południowej. Jeden z najlepiej opisanych przez badaczy przykładów stanowi niemiecka reakcja na wyniki opublikowane w 2001 roku. Ciekawe jest również porównanie podejścia do rankingów prezentowanego przez naszych dwóch sąsiadów - Niemców i Czechów. Po publikacji pierwszych wyników z badań PISA 2000 rezultaty uzyskane przez czeskich i niemieckich piętnastolatków były bardzo podobne, co więcej - różnice w tych rezultatach nie były istotne statystycznie. W obu krajach wyniki były niższe niż średnia OECD wszystkich uczestniczących w badaniu nastolatków ${ }^{1}$. Pomimo jednak zbliżonych wyników, to co nastąpiło później ukazuje odmienne podejście do tego typu rankingów. Wśród badaczy ukuło się wyrażenie „PISA shock” i dotyczy ono reakcji niemieckiego społeczeństwa, które miało aspiracje do przodowania w rankingu ${ }^{2}$ i oczekiwało dużo wyższych rezultatów. Jednakże, rankingowe miejsce Niemiec wywołało ogólne zamieszanie i nawet było postrzegane jako kryzys systemu edukacyjnego tego kraju. W każdej badanej kategorii wyniki były niższe niż średnia OECD. W czytaniu na przykład niemieccy piętnastolatkowie zdobyli 484 punkty (przy średniej OECD równej 500 pkt.) i znaleźli się na dwudziestym pierwszym miejscu $\mathrm{w}$ rankingu. $\mathrm{W}$ matematyce zajęli dwudzieste miejsce, zdobywając 490 punktów, jak również to samo miejsce w rankingu uzyskali w obszarze nauk przyrodniczych, osiągając wynik 487 punktów ${ }^{3}$. Rozpoczęła się szeroka debata na temat reform szkolnictwa. David Greger, autor artykułu When PISA doesn't matter. The case of Czech Republic and Germany, jest zdania, iż po publikacji wyników w niemieckim społeczeństwie wytworzył się klimat do zmian, który wcześniej (w dużej mierze przez autonomiczną politykę edukacyjną w poszczególnych landach) nie mógł zaistnieć w takiej skali W roku szkolnym 2004/2005 we wszystkich landach wprowadzone zostały krajowe normy nauki języka niemieckiego, matematyki, pierwszego języka obcego, co stało się podstawą opracowania nowego programu nauczania ${ }^{5}$. Od roku 2006 uczniowie podlegają ogólnokrajowej ocenie, która ma sprawdzać, czy wszędzie spełniane są wyznaczone standardy. Powołano w tym celu In-

${ }^{1}$ D. Greger, When PISA does not matter? The case of Czech Republic and Germany, Human Affairs, 2012, 22, s. 31-32.

2 Tamże.

${ }^{3}$ CESifo Forum 3/2002, Max Planck Institute for Educational Research, Berlin, s. 49, źródło: http://www.cesifo-group.de/DocDL/Forum302-dice.pdf, [dostęp: 23.01.2018].

${ }^{4}$ D. Greger, When PISA does not matter?, s. 37-38.

${ }^{5}$ Tamże. 
stytut ds. Rozwoju Jakości w Edukacji (Institut zur Qualitätsentwicklung im Bildungswesen). Wprowadzono wiele programów, w tym między innymi Projekt LiD Lesen, którego celem jest promocja czytelnictwa, projekt SINUS do nauczania matematyki i przedmiotów ścisłych. Zmiany były również zauważalne w obszarze edukacji imigrantów - wzbogacanie oferty szkolnej, prowadzenie poradnictwa edukacyjnego i zawodowego, czy szkoleń z zakresu zagadnień międzykulturowości dla nauczycieli ${ }^{6}$. Jednak, jak twierdzą badacze, niemieckie reformy nie odpowiedziały na główny problem zidentyfikowany przez badania PISA, którym był silny związek między społeczno-ekonomicznym pochodzeniem uczniów a ich osiągnięciami edukacyjnymi, nie podjęto działań zmierzających do zmiany wczesnej selekcji w strukturze edukacji ${ }^{7}$. Florian Waldow w swoim artykule What PISA Did and Did Not Do: Germany after the "PISA-shock" zaznacza, iż obszary, w których niemieccy nastolatkowie odnieśli porażkę wcale nie były wcześniej nieznane specjalistom, jednak publikacja badań PISA na tak szeroką skalę i odbiór wyników przez opinię publiczną bardzo te problemy uwidoczniło ${ }^{8}$. W 2008 roku Klaus-Jürgen Tillmann, Kathrin Dedering, Daniel Kneuper, Christian Kuhlmann i Isa Nessel opublikowali książkę PISA als bildungspolitisches Ereignis, będącą wynikiem szczegółowych analiz dotyczących badań PISA. Badacze skupili się na tym, jak wyniki badania prowadzonego przez OECD były odbierane w czterech landach ${ }^{9}$ : Brandenburgii, Bremie, Turyngii oraz Nadrenii-Palatynacie. Zwrócono uwagę przede wszystkim na trzy perspektywy znaczenia wyników PISA dla:

1) zarządzania i administracji;

2) uzasadniania i legitymizacji podejmowanych decyzji;

3) związku między polityką edukacyjną a badaniami edukacyjnymi ${ }^{10}$.

W badaniu wykorzystano cztery typy danych:

- artykuły prasowe;

- dokumenty ministerstw edukacji;

- dokumenty parlamentarne;

- wywiady z ekspertami z ministerstw, związków nauczycieli oraz badaczami edukacji.

Autorzy książki dostrzegają specyfikę czasu, w którym ogłoszono wyniki PISA. Zbiegł się on bowiem z planowanymi (w niektórych landach) zmianami; ukazują fenomen - publikacja wyników PISA była punktem przeło-

${ }^{6}$ Tamże, s. 38.

7 Tamże.

${ }^{8}$ F. Waldow, What PISA Did and Did Not Do: Germany after the "PISA-shock", European Educational Research Journal, 2009, 8, 3, s. 476.

9 Tamże, s. 477.

${ }^{10}$ Tamże. 
mowym w dyskusji na temat polityki oświatowej ${ }^{11}$, jednocześnie autorzy nie zgadzają się z funkcjonującym (według nich) mitem, iż scentralizowane zmiany czy reformy szkolnictwa to wynik badań PISA. Na dowód przedstawiają różne reakcje w badanych landach. Zarówno w Brandenburgii, jak i Nadrenii-Palatynacie decyzję o wprowadzeniu centralnego oceniania oraz testowania podjęto przed publikacją wyników PISA (choć jak zaznacza autor artykułu What PISA Did and Did Not Do... w Brandenburgii zmiany nabrały tempa dopiero po ich publikacji), natomiast Turyngia zdecydowała się na ten krok już po publikacji rezultatów ${ }^{12}$, jednak odniesienia do wyników PISA miały tu służyć jedynie utwierdzeniu w przekonaniu o słuszności tego kroku, a nie być przez nie powodowane. Reakcje na wyniki PISA w każdym z landów były zależne od rezultatów uzyskanych przez nastoletnich mieszkańców konkretnych regionów oraz od stylu rządzenia. W Turyngii na przykład dobre wyniki uczniów tego landu pozwoliły ówczesnemu ministrowi edukacji przekonać opinię publiczną, iż debata na temat struktury szkoły jest zbędna ${ }^{13}$.

Podsumowując te reakcje, jakkolwiek autorzy książki PISA als bildungspolitisches Ereignis przekonują, iż zmiany w systemie edukacji były planowane wcześniej, należy podkreślić, iż relatywnie słabe wyniki uzyskane przez niemieckich uczniów i zestawienie ich w rankingu stało się przyczynkiem do szerokiej, ogólnospołecznej debaty. Wyniki te spowodowały poczucie kryzysu, zmusiły decydentów do reagowania ${ }^{14}$. Innym efektem publikacji punktów uzyskanych przez uczniów w tym teście, a przy tym niezwykle silnie natężonej dyskusji na jej temat, była też ekspansja edukacyjnych badań empirycznych na terenie Niemiec $^{15}$. Zaangażowanie społeczeństwa w debatę nad poprawą wyników, duża liczba tekstów publikujących wyniki PISA lub odnoszących się do tych badań pokazuje, jak duże poruszenie wywołało w Niemczech to badanie.

Na początku artykułu podkreśliłam, że po pierwszej turze badań (PISA 2000) wyniki uczniów niemieckich oraz czeskich były bardzo zbliżone. Jednak to, co wywołało efekt PISA-shock w Niemczech, u Czechów nie stało się przyczyną prowadzenia ożywionej debaty na temat PISA. Wyniki przyjęto z ogólnym zadowoleniem i nie stanowiły one wówczas podstawy do wprowadzania reform edukacyjnych ${ }^{16}$. Zaprezentowane reakcje dotyczyły okresu po publikacji pierwszych i drugich wyników badań (PISA 2000, PISA 2003),

\footnotetext{
11 Tamże, s. 481.

12 Tamże, s. 478-479.

13 Tamże, s. 480.

14 Tamże, s. 481.

15 Tamże.

16 D. Greger, When PISA does not matter?, s. 39.
} 
natomiast ciekawie prezentują się osiągnięcia tych krajów po szóstej już turze badań (PISA 2015). W bazie danych OECD możemy odszukać szczegółowe opisy dotyczące wyników niemieckich uczniów oraz trendów zaobserwowanych przez lata prowadzenia tegoż badania i przeczytać, że:

Średni wynik Niemiec w naukach przyrodniczych utrzymuje się na stałym poziomie od 2006 roku, kiedy nauki przyrodnicze były głównym obszarem badań. W stosunku do roku 2012, kiedy nauki przyrodnicze nie były głównym obszarem badań, wynik uczniów spadł o 15 punktów. Osiągnięcia kraju w czytaniu od roku 2000 systematycznie rosną, podczas gdy poziom umiejętności matematycznych od 2003 roku nie zmienia się znacząco ${ }^{17}$ [tłum. własne - P.B.].

Wyniki czeskich piętnastolatków w porównaniu z poprzednimi edycjami badania prezentują się następująco (dane pochodzą z czeskiego raportu Mezinárodní šetření PISA 2015 ${ }^{18}$ ):

- w zakresie umiejętności matematycznych wyniki uczniów są zbliżone do wyników średniej OECD (w badaniu PISA 2000 wyniki były poniżej średniej OECD);

- osiągnięcia czytelnicze piętnastolatków są nieco poniżej średniej OECD, w badanym obszarze lepsze wyniki mają dziewczęta, choć różnica między czeskimi uczniami systematycznie maleje - w obu obszarach od 2006 roku (po znaczącym wzroście) obserwuje się spadek zdobywanej liczby punktów ${ }^{19}$.

Opisany powyżej przykład, ukazujący różne podejścia tych dwóch społeczeństw i wykorzystania wyników PISA, może stanowić wstęp do rozważań na temat zmian w systemach edukacyjnych pojawiających się w krajach uczestniczących w badaniu. Wśród licznych badaczy zajmujących się tą kwestią na uwagę zasługują choćby wymienieni w artykule Seeing education with one's eyes and through PISA lenses: considerations of the receptions of PISA in European countries, autorstwa Louisa Miguela Carvalho i Esteli Costa. Wskazali oni na badania opisujące reakcję Szwajcarii (T. Bieber, K. Martens, 2011); francuskie podejście do wyników PISA (M. Dobbins, K. Martens, 2012); sytuację w Niemczech (H. Ertl, 2006; F. Waldow, 2009); Szkocji (S. Grek, 2009); Turcji (B. Gür, Z. Çelik, M. Özoğlu, 2012); Finlandii (M. Rautalin, P. Alasuutari, 2009;

17 Źródło:http://www.oecd.org/pisa/pisa-2015-Germany.pdf, [dostęp: 22.01.2018] (oryginał: Germany's mean score in science has remained stable since 2006, when science was the main domain assessed. But the country's mean score in science fell by 15 points since 2012 when science was a minor domain. The country's mean score in reading has steadily improved since PISA 2000, while its mean mathematics performance has not changed significantly since 2003 Tables I.2.4a, I.4.4a and I.5.4a).

${ }_{18}$ R. Blažek; S. Příhodová, Mezinárodní šetření PISA 2015. Národní zpráva Přírodovědná gramotnost, Česká školní inspekce, Praha 2016; źródło: http://www.csicr.cz/Csicr/media/ Prilohy/PDF_el._publikace/Mezinárodn\%C3\%AD\%20šetřen\%C3\%AD/NZ_PISA_2015.pdf, [dostęp: 27.01.2018].

19 Tamże, s. 8-9. 
R. Rinne, J. Kallo, S. Hokka, 2004); Szanghaju (S. Sellar i B. Lingard, 2013); Japonii (K. Takayama, 2008) ${ }^{20}$. Tematyką reakcji społeczeństw po opublikowaniu badań PISA zajmowali się także S. Taut, D. Palacios (2016), opisując sytuacje panującą w Chile.

Wśród krajów, które jeszcze przed pierwszą turą badań PISA (2000) uczestniczyły w porównywaniu czy ocenach międzynarodowych przy okazji innych projektów prowadzonych przez OECD, na uwagę zasługują Belgia, Francja, czy Węgry. Po opublikowaniu rezultatów badań PISA debata na ich temat była bardzo publiczna i polityczna, a samo narzędzie zostało wnikliwie zanalizowane i zinterpretowane przez społeczności naukowe ${ }^{21}$. Dla Węgrów dane dostarczane przez badania, a nawet słownictwo generowane $w$ raportach OECD, stały się narracją wykorzystywaną na potrzeby krajowej polityki edukacyjnej. W Portugalii wyniki badań PISA są traktowane jako zastępcze narzędzie oceny krajowej, a informacje uzyskiwane dzięki raportom służą do legitymizacji rządowych działań w zakresie edukacji²2.

W 2011 roku Jo-Anne Baird z zespołem przeprowadziła badania odnośnie reakcji na wyniki PISA w sześciu krajach. Polegało ono na skonfrontowaniu wyników zdobywających wysokie rezultaty uczniów z Kanady i Szanghaju (Chiny) z uczestnikami osiągającymi wyniki oscylujące wokół średniej OECD - Anglią, Francją, Norwegią i Szwecją, jako że taki wybór uczestników przez badaczy był motywowany tym, iż w krajach tych obserwuje się ciekawe oddziaływania PISA na politykę edukacyjną ${ }^{23}$. W Norwegii, której średnie wyniki (w latach 2000,2003) były niższe aniżeli średnia OECD, a także niższe niż wyniki skandynawskich sąsiadów (Szwecji, Danii, Finlandii), międzynarodowe porównywanie się dało efekt $\mathrm{w}$ postaci szeregu reform edukacyjnych, obejmujących zarówno obszar ocen, jak i polityki programowej ${ }^{24}$. Dodatkowych, uzupełniających danych dotyczących zmian w tym kraju dostarczają opisy Sverre Tveit, z których wynika, iż reformy przeszła zarówno edukacja na poziomie podstawowym jak i średnim, stworzono projekty rządowe, których zadaniem było promowanie oceniania kształtującego, powołania nowego krajowego systemu oceny jakości z testami oraz stworzenia nowych przepisów regulujących przeprowadzanie egzaminów ${ }^{25}$.

${ }^{20}$ L.M. Carvalho, E. Costa, Seeing education with one's eyes and through PISA lenses: considerations of the receptions of PISA in European countries, Discourse: Studies in the Cultural Politics of Education, 2014, s. 3.

21 Tamże, s. 4.

22 Tamże, s. 3.

23 S. Taut, D. Palacios, Intended and unintended interpretations and uses of PISA results: A consequential validity perspective, RELIEVE e-Journal of Educational Research, Assessment and Evaluation, 2016, 22(1), s. 7.

24 Tamże, s. 8-9.

25 Tamże, s. 9. 
We Francji najwięcej obaw o skuteczność edukacji generowały wyniki w obszarze czytelnictwa. Jakkolwiek francuscy piętnastolatkowie osiągali rezultaty podobne do średniej OECD, to zauważalna i niepokojąca była duża rozbieżność między wynikami poszczególnych uczniów. W tym obszarze badań był zarówno duży odsetek uczniów osiągających wysokie wyniki oraz tych, których rezultaty były niewystarczające. Po przeanalizowaniu punktów zdobywanych przez nastolatków we Francji, również i tam ogłoszono serię reform w szkolnictwie podstawowym. Wprowadzono strategię zwalczającą analfabetyzm, a także zwiększono autonomię szkół, co miało prowadzić do usprawnienia pomocy uczniom najsłabszym ${ }^{26}$.

Z kolei, w badaniach Sellar i Lingard z roku 2013 ukazano, że zarówno w Anglii, USA, jak i Australii PISA jest narzędziem, które w tych krajach wykorzystuje się do wdrożenia reform (wyniki są w nich prezentowane dla poparcia reform, stanowią raczej ich usprawiedliwienie, a nie przyczynę). Dyskurs w polityce edukacyjnej jest oparty na tak zwanych „pozytywnych dowodach tego co działa" 27.

\section{Niezamierzone konsekwencje}

Co trzy lata raporty publikowane przez OECD oraz raporty krajowe, w których interpretuje się i uwydatnia własne wyniki, dostarczają wielu różnych danych. Są one na tyle rozpowszechnione, iż stanowią znaczącą bazę nie tylko dla badaczy, ale również dla mediów czy polityków. Ułożone w wykresy wyniki zaczynają swój, często pozbawiony jakiejkolwiek głębszej interpretacji, obieg wśród opinii publicznej. Louis Miguel Carvalho i Estela Costa uważają, że poprzez przeprowadzanie tego międzynarodowego porównywania, program PISA ustala położenie każdego z uczestniczących krajów w wyimaginowanej, konkurencyjnej i odnawialnej co trzy lata przestrzeni ${ }^{28}$. Stanowi więc instrument polityki, dzięki któremu OECD nie musi już polegać na danych statystycznych, ponieważ generuje własne ${ }^{29}$. Samo zaś publikowanie rankingów może stać się interwencją w politykę edukacyjną krajów uczestniczących w badaniu.

Inną kwestię poruszyli Sandy Taut oraz Diego Palacios, których rozważania dotyczyły standardów testów w odniesieniu do programu prowadzonego przez OECD. Badacze zwrócili uwagę na standardy testów stosowanych w edukacji i psychologii, opracowane przez American Educational Research

\footnotetext{
${ }^{26}$ Tamże, s. 7.

${ }^{27}$ L.M. Carvalho, E. Costa, Seeing education with one's eyes and through PISA lenses, s. 4.

28 Tamże, s. 6.

29 Tamże, s. 2.
} 
Association (AERA), American Psychological Association (APA), oraz National Council on Measurement in Education (NCME). Wskazują one kryteria oceny jakości testów, wymieniając trzy główne aspekty, które twórca testu powinien brać pod uwagę. Są to ważność, precyzja i błędy pomiaru oraz uczciwośćc ${ }^{30}$. Jednym z zaleceń do tworzenia testów jest włączanie do ich walidacji dowodów opartych na konsekwencjach ich stosowania. Twórca powinien jasno określić, jak mają być interpretowane wyniki uzyskane dzięki stosowaniu testu oraz zatwierdzić możliwe jego zastosowania ${ }^{31}$. Tymczasem zauważalne są nadinterpretacje danych pochodzących z raportów $\mathrm{OECD}$, co prowadzi do negatywnych skutków. Dowody na to zjawisko zgromadzili wymienieni powyżej badacze. Uważają, iż niekorzystnymi efektami prowadzenia badań PISA w takiej formie są dyskusje (zwłaszcza w krajach uzyskujących niskie bądź niezadowalające ogół społeczności wyniki), sprowadzone do obarczania winą za niepowodzenia wybrane grupy (np. nauczycieli). W konsekwencji tego w społeczeństwach wytwarza się "kulturę winy". Innym negatywnym efektem jest wykorzystywanie wyników badań PISA do przeforsowywania reform, które (bez tych wyników) byłyby analizowane bardziej szczegółowo. Na potwierdzenie występowania tego zjawiska Taut i Palacios podają przykłady czterech krajów: Turcji, Hiszpanii, Japonii oraz Chile. W Turcji wyniki piętnastolatków, zarówno w badaniu PISA 2003 jak i 2006, były poniżej średniej OECD. Opinia publiczna skupiała się głównie na rankingach i pomijała inne dane pochodzące z raportów. Choć reformę szkolnictwa przygotowywano wcześniej, to odbiór wyników PISA jako niewystarczających stał się motorem do wprowadzania zmian, które w innym wypadku podlegałyby dłuższej dyskusji ${ }^{32}$. Nadużycia w interpretacji wyników zauważono również w japońskiej prasie. Wytworzyła ona obraz upadku edukacji i poczucia kryzysu, mimo iż wyniki (PISA 2000 oraz PISA 2003) nie miały tendencji spadkowej, nie różniły się istotnie statystycznie (poza problemami w obszarze czytelnictwa, które były zidentyfikowane jeszcze przed przystąpieniem do badań OECD) ${ }^{33}$. Kwestia zmian w polityce edukacyjnej w Hiszpanii została także szczegółowo opisana. W 2013 roku wprowadzono wiele reform, które były uzasadnione słabymi wynikami uczniów w badaniu PISA 2012. Badacze podkreślają, iż interpretacja hiszpańskich wyników, dokonana zarówno przez polityków jak i dziennikarzy (Jornet, 2013, 2016c; Carabaña, 2008), była nieprawidłowa ${ }^{34}$. Polityka edukacyjna kraju prowadzona na podstawie niedokładnie zinterpretowanych rankingów ma swoje nega-

\footnotetext{
${ }^{30}$ S. Taut, D. Palacios, Intended and unintended interpretations and uses of PISA results, s. 2.

31 Tamże.

32 Tamże, s. 9.

33 Tamże.

34 Tamże, s. 9-10.
} 
tywne skutki. Sytuacja w Chile - kraju, który zaczyna być postrzegany jako „dobry uczen", potrafiący poprawiać swoje wyniki - jest podobna. Wyniki są wykorzystywane do celów politycznych i w kraju buduje się poczucie kryzysu wspierane rankingami (w których Chile pozostawało poniżej średniej OECD, jednak uzyskiwało coraz lepsze wyniki) ${ }^{35}$.

\section{Podsumowanie}

Podsumowując opisane powyżej przykłady, należy zwrócić uwagę na reakcje krajów uczestniczących w badaniu PISA. Poza pozytywnymi skutkami, które mogą pojawić się po ogólnospołecznych debatach na temat szkolnictwa czy dzięki możliwości poznawania systemów edukacyjnych w innych krajach uczestniczących w programie OECD, istotne są możliwe skutki negatywne. Niedokładnie interpretowane dane, pobieżnie przedrukowywane w prasie rankingi służą także walkom politycznym, ciągłemu porównywaniu się zarówno w kraju, jak i międzynarodowo, czy forsowaniu pobieżnie przygotowywanych reform - a więc głębokiemu zmienianiu systemów edukacyjnych. PISA jako narzędzie wzajemnego nadzoru przyczynia się do konstruowania narracji w polityce edukacyjnej, ma znaczenie dla decydentów i przez to również może sterować systemami szkolnymi. Należy więc zadać sobie pytanie: czy ciągłe poprawianie wyników i próby uplasowania się na wyższych miejscach w rankingach to dobra droga dla pojedynczych systemów edukacyjnych? Drugim pytaniem, które się tu pojawia jest zagadnienie pewnego urynkowienia badań PISA i ich wyników. Można wyrażać obawy, czy badania te nie polegały na handlowej zasadzie, że najpierw wytwarza się potrzebę, a potem dostarcza produkt, który ją „cudownie” zaspokaja. Można bowiem zauważyć, że niemal wszędzie tam, gdzie pojawiło się badanie PISA następowało uruchomienie procesu "permanentyzacji reform szkolnych”. Tutaj z kolei pojawiają się już pytania o jawne i ukryte relacje między polityką a edukacją.

\section{BIBLIOGRAFIA}

Baird J.A., Isaacs T., Johnson S., Stobart G., Yu G., Sprague T., Daugherty R., Policy Effects of PISA, Oxford University Centre for Educational Assessment, 2011.

Blažek R., Příhodová S., Mezinárodní šetření PISA 2015. Národní zpráva Př́rodovědná gramotnost, Česká školní inspekce, Praha 2016; ; źródło: http://www.csicr.cz/Csicr/ media/Prilohy/PDF_el._publikace/Mezinárodn\%C3\%AD\%20̌̌etřen\%C3\%AD/NZ_ PISA_2015.pdf, [dostęp: 27.01.2018].

\footnotetext{
35 Tamże, s. 10.
} 
Carvalho L.M., Costa E., Seeing education with one's eyes and through PISA lenses: considerations of the receptions of PISA in European countries, Discourse: Studies in the Cultural Politics of Education 2014.

CESifo Forum 3/2002, Max Planck Institute for Educational Research, Berlin źródło: http:/ / www.cesifo-group.de/DocDL/Forum302-dice.pdf, [dostęp: 23.01.2018].

Country Note OECD http:/ / www.oecd.org/pisa/pisa-2015-Germany.pdf

Greger D., When PISA does not matter? The case of Czech Republic and Germany, Human Affairs, 2012, 22.

OECD: Sample Tasks from the PISA 2000 Assessment. Reading, Mathematical and Scientific Literacy.

OECD: Results by Country; źródło: http://www.oecd.org/pisa/\#d.en.198776

OECD: Education GPS. THE WORLD OF EDUCATION AT YOUR FINGERTIPS

Taut S., Palacios D., Intended and unintended interpretations and uses of PISA results: A consequential validity perspective, RELIEVE e-Journal of Educational Research, Assessment and Evaluation, 2016, 22(1).

Waldow F., What PISA Did and Did Not Do: Germany after the "PISA-shock", European Educational Research Journal, 2009, 8, 3. 